\title{
Landscape Values as a Driving Force to Increase Nature Conservation. Environmental and Planning Policies as a Possible Integration
}

\author{
Donatella Cialdea $^{1, *(1)}$ and Sandro Privitera ${ }^{2}$ \\ 1 L.a.co.s.t.a. Laboratory, University of Molise, 86100 Campobasso, Italy \\ 2 C.U.T.G.A.N.A Center, University of Catania, 95123 Catania, Italy; sandro.privitera@unict.it \\ * Correspondence: cialdea@unimol.it
}

Citation: Cialdea, D.; Privitera, S.

Landscape Values as a Driving Force to Increase Nature Conservation. Environmental and Planning Policies as a Possible Integration.

Sustainability 2021, 13, 6621. https:// doi.org/10.3390/su13126621

Academic Editor: Thomas A. Clark

Received: 17 April 2021

Accepted: 7 June 2021

Published: 10 June 2021

Publisher's Note: MDPI stays neutral with regard to jurisdictional claims in published maps and institutional affiliations.

Copyright: () 2021 by the authors. Licensee MDPI, Basel, Switzerland. This article is an open access article distributed under the terms and conditions of the Creative Commons Attribution (CC BY) license (https:// creativecommons.org/licenses/by/ $4.0 /)$.

\begin{abstract}
Landscape values are addressed by planning tools in several diversified ways. Many European countries have joined the European Landscape Convention which just turned 20 last year. This work aims at investigating its implementations and relationships with general and local planning tools, focusing on two main objectives: the first one concerns the analysis of principles regulating regional strategies, deriving from European dictates and State norms. It has been focused in the Sicily region in Italy, the largest island in the Mediterranean basin. The second objective concerns the in-depth analysis of territories of a fragile nature in which the two terms that characterize the landscape, culture and nature, merge together. This paper consists in gathering information deriving from the various planning levels, proposing a comparison methodology which takes into account physical-environmental and landscape-visual features in some sample cases within protected areas, but in a highly urbanized context. A system and database were created and implemented within the geographic information system, drawing up a comparison between environmental requirements and development strategies.
\end{abstract}

Keywords: landscape performances; protected areas; geographic information system; planning tools

\section{Introduction}

The landscape brings together two terms: nature and culture. Scholars of different fields are interested in landscape in order to highlight its peculiarities and the risks due to the land use changes it faces. The European Landscape Convention (ELC), signed in 2000 and to which member states continue to adhere to today, is just turning 20 years old. As known, it reads: "Landscape means an area, as perceived by people, whose character is the result of the action and interaction of natural and/or human factors" [1,2]. Its major innovation consists in the ability to underline the impact of public landscape issues and it highlights the importance in the participation of both people and local authorities. The main concern is its application in European countries: the ELC expects individual member states to develop their own evaluation methodologies, aimed at managing their different geographical contexts. The problem is, thus, how these policies fit into each country's planning tools, and then how each state favours their implementation through regional strategies, which are also always highly diversified.

Furthermore, the relationship with urbanized centres is one of the crucial issues to be addressed. In principle, urbanization, which began with the industrial revolution of the 18th century, has produced a process in which the city and its suburbs have grown in different ways and times [3]. By virtue of the changes in the shape and size of the city, the relationship between the city and nature has changed, with implications often seen as negative factors, gradually leading to local identity loss. Thus, the concept of cultural landscape has changed over time, as a form that has gradually adapted to changes in land use $[4,5]$. As the literature argues, there should be a favourable mutual exchange 
between cities and natural resources [6-10], even often seen as a great competition [11]. This issue is further compounded by the presence of non-urbanized areas surrounded by highly urbanized contexts $[12,13]$ and by the complex management processes, especially in peri-urban areas of larger cities [14-17].

The focus is on the role of spatial planning systems which must be integrated with landscape issues $[18,19]$. The complexity of landscape planning issues necessarily combines the aims of spatial planning tools with requests of local communities for their economic development $[2,20,21]$. The proximity of naturalistically valuable areas with urban centres is, therefore, a central topic for policies relating to sustainability. The thesis, supported in this paper, is not to defend the natural context by considering settlement expansion only as a factor to be stemmed, but rather to highlight the need for greater accuracy in urban policies. Thereby, natural areas could be a driver for the improvement of quality of life, in urban settlements too.

The research, for several years led by the authors, aims at deepening this relationship, in search of a balance between these two requirements. The case study is Sicily Island, and in particular its coastal areas, in which extreme conflict occurs. The coast, in fact, is the environment in which the increasing economic development (also linked to tourist exploitation) needs to be combined with the strong landscape values of these areas. For this purpose, it was decided to investigate the inconsistencies that inevitably derive from conflicting planning tools.

The research focused mainly on a particular landscape context, that is the terraced landscape-often recurring in the European panorama-which is interesting from several points of view. As far as the literature is concerned, different conditions exist in the countries of the Mediterranean Basin. In the Italian context, in particular, the discrepancy between the planning tools' intent and the real situation emerged: planning and management tools often collide with the rapid evolution of the landscape (for example following calamitous events). Terraces are a landscape scenery type deriving from a particular slope morphology. They constitute a sensitive indicator of local transformation, passing from the more traditional role related to agricultural field productions (fruit, oil and wine) to the more recent role related to tourist activities. Several studies and research projects have been analysed, investigating their geographical distribution and their functions. Terraces are recognized as "cultural landscapes": many of them are included in the UNESCO World Heritage List, as "places which testify to the creative genius, social development and the imaginative and spiritual vitality of humanity" [22]. They are widely represented in many countries: China, Philippines, Switzerland and eight European countries: Cyprus, Croatia, France, Greece, Slovenia, Spain, Switzerland and also Italy [23]. A further peculiarity of these landscapes consists in their building techniques, so much so that UNESCO decreed the inclusion of the "art of dry-stone walling" (by stacking stones upon each other, without any mortar) in the Intangible Cultural Heritage List [24]. Terraces also have an important function for soil conservation: in fact, they play a key role in contrasting slope degradation and are useful to reduce soil erosion phenomena. Moreover, agricultural activities carried out on them increase the effectiveness of soil protection [25]. They also have an important impact on the geological features, related to the substrate origin and to the soil properties [26]. They act directly on hydrogeological processes: transforming the natural slope, improving the water drainage $[27,28]$ and reducing hydrological connectivity [29], runoff times $[30,31]$ and consequently the erosive processes. After comparing similar situations in European countries, the case study refers to Italy, characterised by mainly mountainous and hilly morphology with very extensive coastal areas, being a peninsula of almost $300,000 \mathrm{~km}^{2}$, with more than $7000 \mathrm{~km}$ of coastline. Therefore, a comparison methodology has been proposed between the planning tools and the management documents of some protected areas, located in Sicily Island. This research has been carried out based on joint experiences developed by the authors during research funded by the European Community (This methodology was carried out by the l.a.co.s.t.a. Laboratory and experimented for the following projects (responsible D. Cialdea): GES.S.TER.—Sustainable Management of 
Coastal Areas, acronym funded by the INTERREG IIIA; SEA-EAS-Environmental and Archaeological Sites funded by the NPPA INTERREG/CARDS-PHARE; Model for the Coastal Landscape Units for the National and Cross-Border Adriatic Coasts funded by the Interlink MIUR Programme. Sandro Privitera participated in all above-mentioned projects.).

As regards the subdivision of the work, the introduction is followed by the methods (which deals with the description of the study area, the definition of the investigation methodology used and finally explores the aspects of protection from a naturalistic point of view and the enhancement of the landscape elements). The next section contains the results and discussion and reflects on the possible expansion of the research, followed by Section 4: conclusions, summarizing the main goals of this paper.

\section{Materials and Methods}

\subsection{Study Area}

The case study is the eastern Sicilian coast at foot of the Etna Mountain, which is the most active volcano in Europe and the highest peak of the whole Mediterranean Basin. In this area, the beauty of the volcanic coastal scenery is evidenced by various protected areas and numerous urban centres with significant historical-artistic elements. The favourable climate, the pedological features of the volcanic soils and the ability of the farmers to terrace much of the coastal strip over the centuries, have given rise to an important historical phase related to the agricultural activities' development with valuable productions, such as vines and citrus fruits. The vegetable and cultivated landscape is under various headings according to altimetry. In particular, the "Mediterranean maquis" and "lemon groves" cover most of the eastern flank up to about $500 \mathrm{~m}$ (Figure 1).

The coastline offers an interesting landscape, characterized by headlands and small creeks, towering cliffs, terraces, and narrow beaches bordered by cliffs. In these areas, human settlement dates back to the period of Greek colonization [32-35]. The combination of these positive elements made these areas particularly attractive starting from the 1960s to 1970s, when the post-war economic development allowed the local population to integrate into rural landscape frameworks in an impactful way: thousands of houses were built without urban norms able to preserve landscape and environmental features.

In the case study area, there are three nature reserves: "La Gurna e Fiumefreddo" (This area includes two SCIs (Riserva Naturale Fiume Fiumefreddo and La Gurna). The whole was established as ONR in 1984. This is the last part of the ancient rear-dune marsh area that until the last century, with the "papyrus" rare species.), "Immacolatelle-Micio Conti" (This reserve consists of a system of nine volcanic caves. Its establishment firstly dated in 1998, was later cancelled and subsequently reinstated in 2013: it was entrusted in management to the Catania University Centre for the Protection and Management of Natural Environments and Agrosystems (C.U.T.G.A.N.A.) to which belongs one of the authors, Sandro Privitera, currently Director of the Palombara Cave Nature Reserve.) and "La Timpa di Acireale". The most attractive is "La Timpa di Acireale", classified as an Oriented Nature Reserve. It was established twice, for the first time in 1984; later, the classification was cancelled and in 1999 the reserve was re-established [36,37]. Its territorial extension is of 225,34 hectares: its surface coincides almost exactly with the perimeter of the Natura 2000 Network ITA070004 SCI (site community importance), similarly named "Timpa di Acireale": it is now classified as a special area of conservation, by virtue of the approval of its management plan. In it, there are numerous landscape and hydrogeological risk constraints. Moreover, there is an important geosite (Palombe' Cave-columnar basalts) of national level volcanological interest. Within the case study, there are also two SCIs to safeguard residual woods (S. Maria La Stella and Linera), increasing the naturalistic value of the whole area. It acquires an exceptional naturalistic importance, being the last remaining forest of the Etna foothills. This forest is also mentioned in numerous ancient texts (see Supplementary Material File S1). 


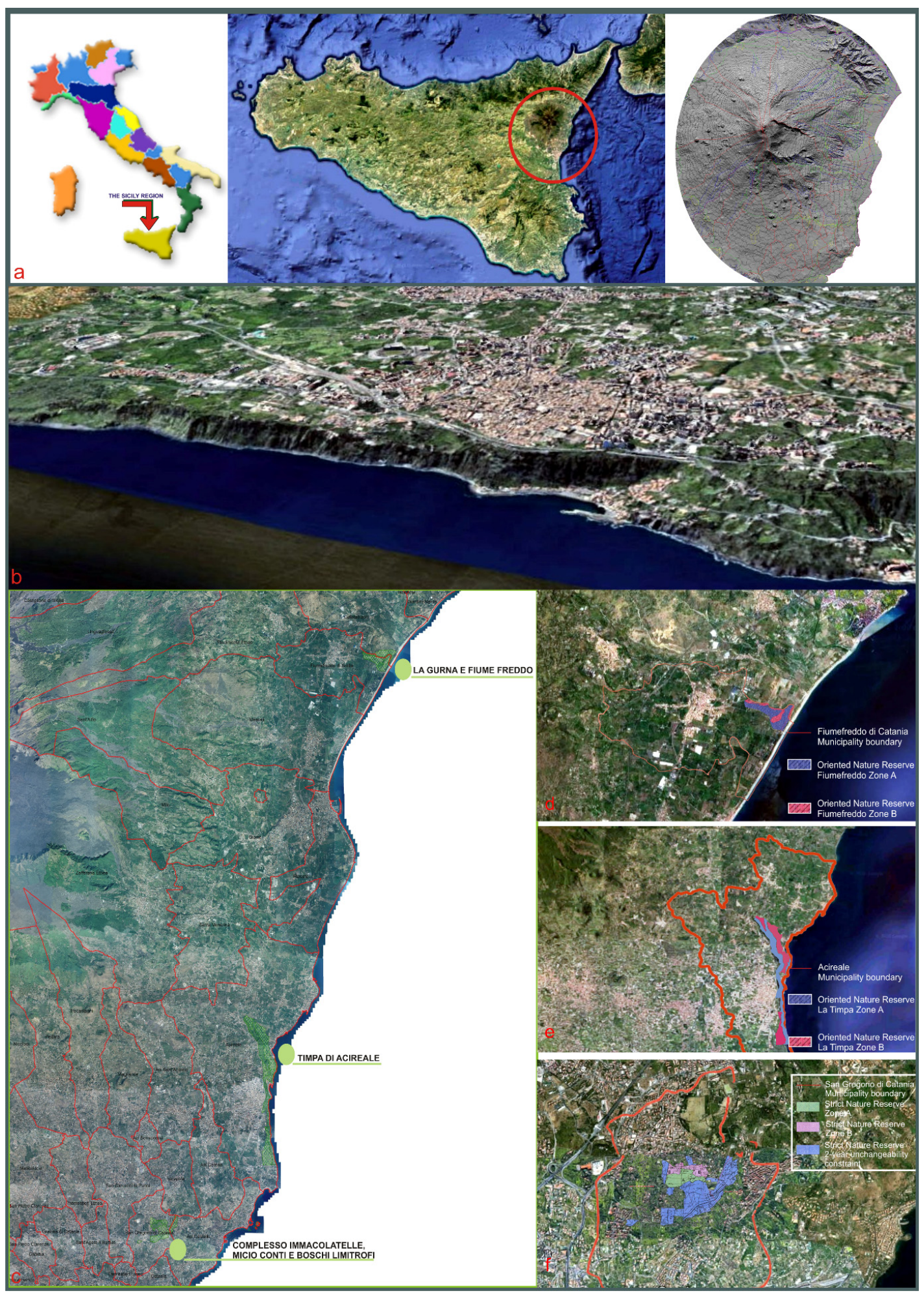

Figure 1. Location of the sample area. (a): Italy, Sicily and the Etna area; (b): the sample area survey vision; (c): identification and location of reserves within that area with orthophotos and technical map; (d): the Gurna lagoon and Fiumefreddo River Reserve; (e): the Timpa of Acireale Reserve; (f): the Immacolatelle-Micio Conti Reserve (source: processing in ArcGis by 1.a.co.s.t.a. Laboratory, Cialdea 2020). 


\subsection{The Methodological Approach}

The methodology is based on the choice of indicators deriving from the literature, as subsequently specified for each element category. They have been examined for sample cases carried out both at European and national level, especially suitable for the analysis of nature protected areas.

While the literature is rich in papers dealing with indicators related to natural resources, the innovative component of this methodology consists in introducing and comparing parameters related to the planning tools previsions.

\subsubsection{Information Collation: From Resources to Indicators}

Regarding "resources systems", most of the investigation was based on resources systems analysis, and they aim at defining the "condition classes", oriented to express the good condition level of these elements: from these conditions derive a "trigger for management response", which necessitates intervention. The general outcome is to evaluate the effectiveness of resource management $[38,39]$. This information was processed starting from elementary data, classified according to the resources systems assessment [40-42]. For each one, following indicators were defined (Table 1):

Table 1. Resources systems indicators.

\begin{tabular}{cc}
\hline 1. PHYSICAL-ENVIRONMENTAL SYSTEM & $\begin{array}{c}\text { Indicators are related to the presence and the } \\
\text { features of SCI/SPAs, nature reserves, parks } \\
\text { and additional interests. }\end{array}$ \\
\hline 2. LANDSCAPE-VISUAL SYSTEM & $\begin{array}{c}\text { Indicators are related to the existing landscape } \\
\text { restriction, residual areas (as "rasule", "saje"), } \\
\text { forests and additional interests. }\end{array}$ \\
3. HISTORICAL-CULTURAL SYSTEM & $\begin{array}{c}\text { Indicators are related to archaeological } \\
\text { restriction, architectural restriction, urban } \\
\text { planning intervention and additional interests. }\end{array}$ \\
\hline 4. AGRICULTURE-PRODUCTIVE SYSTEM & $\begin{array}{c}\text { Indicators are related to land use for } \\
\text { agricultural activities, land use for agricultural } \\
\text { agri-food, land use for organic activities and } \\
\text { additional interests. }\end{array}$ \\
\hline
\end{tabular}

The new step evaluates qualitative and quantitative aspects of "landscape values". Additionally, in this case, literature samples-dealing with the issue of landscape quality assessment-were examined [4,43]. In particular, the data collected relating to resources systems indicators were entered in a database, according to previous experimental application in research for the territory of other regions [44-47], especially for the protocol defined in agreement with the Molise Region for the creation of the new regional landscape plan. Its main perspective was to improve the protection of the territory's assets, refine the landscape value settings and to enhance the potential of sustainable development. "Values" have always been examined in relation to the presence of "detractors" who in fact change the value itself. These "detractors" are elements—related to infrastructural, industrial, or energy assessments-that invaded the territory over time, creating an uncontrolled development of the territory itself. These elements, therefore, have been named "detractors", meaning the presence of elements that lower the landscape values previously identified and evaluated (see Table 2). They are: 
Table 2. Resources systems detractors.

\begin{tabular}{cc}
\hline 1. PHYSICAL-ENVIRONMENTAL SYSTEM & $\begin{array}{c}\text { Detractors are related to the presence and the } \\
\text { features of land restriction such as seismic, } \\
\text { hydro-geological and restriction by L. } \\
445 / 1908 \text { and additional trouble. }\end{array}$ \\
\hline 2. LANDSCAPE-VISUAL SYSTEM & $\begin{array}{c}\text { Detractors are related to the existing } \\
\text { wind-power and ground-mounted } \\
\text { photovoltaic plants, quarries, suburban sprawl } \\
\text { and additional trouble. }\end{array}$ \\
3. HISTORICAL-CULTURAL SYSTEM & $\begin{array}{c}\text { Detractors are related to investigation about } \\
\text { preservation conditions, private property, } \\
\text { access conditions and additional trouble. }\end{array}$ \\
\hline 4. AGRICULTURE-PRODUCTIVE SYSTEM & $\begin{array}{c}\text { Detractors are related to the presence of } \\
\text { industrial sites, special districts, other and } \\
\text { additional trouble. }\end{array}$ \\
\hline
\end{tabular}

Subsequently, a comparison with local undertaken efforts has been carried out.

Study areas have been analysed focusing on the planning and management tools in force, aimed at highlighting interventions carried out or to be carried out, oriented to the protection from a naturalistic point of view or to the enhancement for their development (tourism and agriculture activities or new urban settlements). Even in this case, methodologies utilised in the literature have been considered [48,49]. Several comparisons of the outcomes of the actions envisaged by the plans were carried out at various levels in different countries [50-54]; also referring to the analysis of this Italian case study [55-57]. After comparing the literature and previous application cases, an innovative phase was carried out: the in-depth examination of planning and management tools, in order to face troubles or to enhance local issues. Therefore, these documents were examined, after dividing them with respect both to the administrative area and to their own purposes (as shown in Table 3). In fact, they have been divided into:

Table 3. Planning and management tools levels.
1. OML
2. ML
3. $\mathrm{AO}$
4. TO
Over-Municipal Level
Municipal Level
Agriculture-Oriented
Tourism-Oriented

The first category includes scientific texts, illustrated documents and statistical databases, including surveys and photos in situ. An important role in this case has been attributed to the historical component, with an in-depth analysis of cultural landscapes, searching for the identity memory, which in some cases has been lost and which in others can still be preserved. The second category includes the processing of geographic data (Materials used for cartographic bases are: Sicilian Region Technical Map (Regional WMS service) and the Digital Terrain Model (LIDAR flight ATA 20,072,008 in GAUSS Boaga $2 \mathrm{~m}$ step data). Moreover, materials used for geographical databases derive from different sources. For Retenatura2000: www.artasicilia.eu/w (accessed on 10 April 2021); for Geological Cartography: www.artasicilia.eu/web/carg/ (accessed on 10 April 2021). Furthermore, for thematic maps: the Sicilian Region GIS Portal (http:/ / www.sitr.regione.sicilia.it/ (accessed on 10 April 2021)); and the GIS ISPRA Portal: www.sinanet.isprambiente.it/it/sia-ispra/ (accessed on 10 April 2021).) relating to the landscape: for this purpose, prescriptive sources are important-not only because they constitute the legal and planning framework, but also because regulations for activities development define the future assessment. Examining these two aspects in parallel - the "past" one (assumed by historical documents) and the "future" one (through the in-depth examination of urban planning tools at regional, urban and sectoral levels) - is the innovative aspect of this work. 


\subsubsection{Final Goal}

Therefore, to conclude the evaluation process in order to define various landscape conditions, a comparison between different parameters—as identified above- - has been made.

As will be seen later in the results section, this methodology leads to the preparation of "analysis schedules" and "interpretation schedules". In this paper, the protected areas of the sample case were analysed as components of the investigated areas repository. In particular, this paper examines in detail the analyses carried out for the "La Timpa di Acireale" reserve. As described above, based on measurements of landscaped values (protected areas, restricted areas, etc.), indicators were identified and evaluated, giving importance to the "upcoming projects", as indicators of "effectiveness".

The methodology includes four cases of interpretation, which are four landscape typology sheets, relating to the conditions of the preserved, disappeared, residual and endangered landscapes.

To sum up:

$\Sigma_{\mathrm{S} 1}(\mathrm{~V}-\mathrm{D})+(\mathrm{UP} / 100)+\Sigma_{\mathrm{S} 2}(\mathrm{~V}-\mathrm{D})+(\mathrm{UP} / 100)+\Sigma_{\mathrm{S} 3}(\mathrm{~V}-\mathrm{D})+(\mathrm{UP} / 100)+\Sigma_{\mathrm{S} 4}(\mathrm{~V}-\mathrm{D})+(\mathrm{UP} / 100) / 4$

$\mathrm{V}=$ values (by indicators for each system S1 to S4);

$\mathrm{D}=$ detractors (by detractors for each system S1 to S4);

$\mathrm{UP}=$ upcoming projects (by projects—calculated in percentage as an increment of the value -for each system $\mathrm{S} 1$ to $\mathrm{S} 4$ );

If $>1$ good condition class $=$ preserved landscape;

If $<1$ warning condition class $=$ endangered landscape.

Furthermore, two intermediate situations have been identified: residual areas (in which some political decision is needed) and disappeared areas (in which some intervention is necessary to preserve the memory of places).

\section{Results and Discussion}

The proposed integrated approach is aimed to improve knowledge and awareness about the strategic choices at policy level. The research was divided into different phases, which produced various results, with the primary aim being to identify landscapes to which to devote more attention.

The first step was oriented to define the investigation areas, inside the macro-areas surrounding the three reserves under study, as described in Section 2.1; the first product was the "investigated areas repository".

The second phase consisted of analysing the numerous planning tools and programming documents: the product related to this phase was the comparison between them and it is particularly innovative, in the writer's opinion. This product, named "planning tools analysis" (added to the analyses carried out in the initial data sheet) is useful for defining "conflict areas". To this end, the third product was drawn up, that is the description of the type of conservation of the landscape features, defined as landscape performances (through the "landscape typology schedules"). For the catalogue, the file was prepared taking into consideration the most significant information. The schedule (Table 4) consists of many parts that can be grouped into four different types of data:

Some factors need to be emphasized: the value of the coastal scenery factor (max value, on the scale 1-5) and the presence of landscape restriction, in addition to the values related to hydrogeological instability. In order to highlight any sort of contradictions-in relation to the wishes expressed by local populations- the following table was drawn up which lists the wishes of the main planning tools, with inconsistencies or conflicts (Table 5); references related to this table are located in the Supplementary Material File S2. 
Table 4. Landscape schedule framework.

1. Identification and position data

This first part of the record, consisting in the geographical data relating to the position of the examined area, is the main phase of the census.

Information includes the province, the municipality and the geographical position (in the WGS84 reference system) with an indication of whether it falls in urban, suburban, mixed or primarily agriculture voted.

2. Lytho-morphology features

Lytho-morphology features with the main dangerousness, and other features related to territorial and environmental systems.

The central part of the schedule contains data related to the specific analysed element, with the brief

3. Description, map and photos

description, the indication of the area peculiarities, the referenced cartography and photos.

4. Rules and norms

The last part contains the main current planning tools in the area under study.

Table 5. Planning and Management Tools Analysis.

\begin{tabular}{|c|c|c|c|c|}
\hline Category & Plan & Year & Main Aim & Reference \\
\hline OML & $\begin{array}{l}\text { Landscape Regional Plan } \\
\text { The Landscape Plan for Areas 8,11, } \\
12,13,14,16,17 \text { in Catania Province }\end{array}$ & 2018 & $\begin{array}{l}\text { The Area No. } 13 \text { Landscape Plan identifies } 12 \text { Landscape sub -areas (SP), } \\
\text { from which the SP8 area of lemon groves of the Ionian coast has been } \\
\text { recognized. Acireale has a peculiar, close and specific relationship both } \\
\text { with the sea and with the volcano. }\end{array}$ & [1] \\
\hline OML & $\begin{array}{l}\text { Catania Province Territorial Plan } \\
\text { Province Territorial Plan. Cognitive } \\
\text { Structural Asset, } 2010 \\
\text { Province Territorial Plan. Proposal } \\
\text { Strategic Asset, } 2010\end{array}$ & 2010 & $\begin{array}{l}\text { It promotes strategies and focuses the intervention priorities in the } \\
\text { metropolitan area of the eastern side of the province of Catania, which is } \\
\text { defined as the most complex territory from the point of view of } \\
\text { infrastructure and interactive relationships with the capital, Catania. } \\
\text { Furthermore, Acireale is the most important centre, rich in cultural and } \\
\text { landscape-environmental heritage. }\end{array}$ & {$[2,3]$} \\
\hline OML & $\begin{array}{l}\text { Nature Reserve Zones } \\
\text { "Timpa di Acireale" Oriented Nature } \\
\text { Reserve }\end{array}$ & 1999 & $\begin{array}{l}\text { In the whole territory of the protected area, scientific research activities } \\
\text { can be carried out by qualified subjects authorized by the managing } \\
\text { body which alone can grant exceptions to the prohibitions and norms. }\end{array}$ & [4] \\
\hline OML & $\begin{array}{l}\text { ITA070004 SAC Management Plan } \\
\text { SCI COD. ITA 070,004 "Timpa di } \\
\text { Acireale" Management Plan POR } \\
\text { 1999.IT.16.1.PO.011/1.11/11.2.9/0345 }\end{array}$ & 2009 & $\begin{array}{l}\text { The SAC (special area of conservation) ITA070004, named "Timpa di } \\
\text { Acireale", is one of the numerous ReteNatura2000 sites of community } \\
\text { importance in Sicily. } \\
\text { Its management plan in force was drawn up in } 2009 \text { and finally } \\
\text { approved in } 2010 .\end{array}$ & [5] \\
\hline OML & $\begin{array}{l}\text { Hydro-geological Management Plan } \\
\text { HMP. Territorial area between } \\
\text { Simeto and Alcantara Rivers, } 2006 \\
\text { Update HMP for the Acireale } \\
\text { Municipality, } 2017 \\
\text { Update HMP for the Hydraulic } \\
\text { Hazard due to flooding phenomena. } \\
\text { Territorial area between Simeto and } \\
\text { Alcantara Rivers, } 2018\end{array}$ & 2018 & $\begin{array}{l}\text { It has the value as a sector territorial plan and is the cognitive, } \\
\text { regulatory and technical-operational tool through which interventions } \\
\text { and actions are planned and rules of use are programmed concerning } \\
\text { the defence against the hydrogeological risk of the Sicilian territory. The } \\
\text { landslides that periodically occurr at Timpa of Acireale are directly } \\
\text { correlated with meteorological events of particular intensity occurring } \\
\text { in the Mediterranean Basin during the winter. }\end{array}$ & [6-8] \\
\hline OML & $\begin{array}{l}\text { Province Waste Management Plan } \\
\text { Strategic Environmental Assessment. } \\
\text { The Città Metropolitana di Catania } \\
\text { Waste Province Plan Revision }\end{array}$ & 2016 & $\begin{array}{l}\text { It has been established by the Metropolitan City of Catania, in } \\
\text { compliance with the precautionary principle which is an informative } \\
\text { principle of EU and international legislation and which "requires the } \\
\text { implementation of actions without delay of contrast in cases where } \\
\text { there is a threat of "serious or irreversible" damage to the environment", } \\
\text { (Art. } 174 \text { of the Amsterdam Treaty, which incorporates Art. } 130 \text { of the } \\
\text { Treaty of Maastricht). }\end{array}$ & [9] \\
\hline ML & $\begin{array}{l}\text { Acireale Municipality Master Plan } \\
\text { Approval of the Acireale } \\
\text { Municipality Master Plan } \\
\text { Decree } 18 \text { January } 2005 \text { updating the } \\
\text { Decree } 4 \text { November } 2003\end{array}$ & 2005 & $\begin{array}{l}\text { It contains the general prescriptions for settlement densities of different } \\
\text { territorial areas. The plan pays attention to the territory of the Timpa } \\
\text { Reserve, for which it refers to the norms of the reserve itself (any } \\
\text { activity must be previously authorized by the management authority) }\end{array}$ & [10] \\
\hline ML & $\begin{array}{l}\text { Acireale Strategic Plan for the } \\
\text { Landscape } \\
\text { Landscape Plan of the Acireale } \\
\text { Municipality }\end{array}$ & 2006 & $\begin{array}{l}\text { Adhering to what is defined by the Strategic Cities Network } 2014-2020 \\
\text { EU Programme activated this governance process in order to mobilize } \\
\text { investors: the main aim was to make Acireale an example for southern } \\
\text { Europe, due to its magnificent territorial potential. }\end{array}$ & [11] \\
\hline
\end{tabular}


Table 5. Cont.

\begin{tabular}{|c|c|c|c|c|}
\hline Category & Plan & Year & Main Aim & Reference \\
\hline ML & $\begin{array}{l}\text { Acireale Municipality Civil } \\
\text { Protection Plan } \\
\text { (Update 2013) }\end{array}$ & 2013 & $\begin{array}{l}\text { It plans all coordinated activities and civil protection procedures to face } \\
\text { and overcome a calamitous event expected in the area. The method } \\
\text { actually involves a real preventive planning of the event, and the same } \\
\text { is based on principles of simplicity, flexibility and efficiency. }\end{array}$ & [12] \\
\hline ML & $\begin{array}{l}\text { Acireale Municipality } \\
\text { Drawing up for the Coastal Public } \\
\text { Property Areas Management Plan } \\
2020 \text { adopted }\end{array}$ & $\begin{array}{l}\text { not yet } \\
\text { approved. }\end{array}$ & $\begin{array}{l}\text { This document is a planning tool which identifies how to use the } \\
\text { seacoast and regulates its utilization; therefore it has important } \\
\text { economic repercussions on the development of the territory, public } \\
\text { health and safeguarding environment. }\end{array}$ & [13] \\
\hline $\mathrm{AO}$ & $\begin{array}{l}\text { “Le Terre di Aci” Local Development } \\
\text { Participation Strategy } \\
\text { 2014/2020 Rural Development } \\
\text { Programme }\end{array}$ & 2016 & $\begin{array}{l}\text { This document provides an analysis of the development and potential } \\
\text { needs of the "Terre di Aci" area and identifies a development strategy. It } \\
\text { includes } 5 \text { municipalities (Acireale Aci Sant'Antonio Acicatena Aci } \\
\text { Bonaccorsi and Valverde). In the municipality of Acireale, citrus } \\
\text { growing constitutes around } 2500 \text { hectares of cultivated land, followed } \\
\text { by viticulture, entering the tourist circuit named "the Wine Roads". }\end{array}$ & [14] \\
\hline $\mathrm{AO}$ & $\begin{array}{l}\text { Atlas of PDO, PGI and TSG products } \\
\text { by Italian Agriculture Ministry } \\
\text { Update } 2018\end{array}$ & 2018 & $\begin{array}{l}\text { List of Italian names, registered in the Register of Protected } \\
\text { Designations of Origin (PDO), Protected Geographical Indication (PGI) } \\
\text { and Traditional Specialties Guaranteed (TSG), EU Regulation No. } \\
1151 / 2012 \text { of the European Parliament and of the Council of } 21 \\
\text { November } 2012 \text { (updated on } 12 \text { February } 2020 .\end{array}$ & [15] \\
\hline $\mathrm{AO}$ & $\begin{array}{l}\text { Citrus Plan (Piano agrumi) } \\
\text { INEA Institute }\end{array}$ & 2008 & $\begin{array}{l}\text { In regard to citrus crops, in 1907, the Experimental Station of Fruit and } \\
\text { Citrus was established in Acireale. In 1967, it was transformed into the } \\
\text { Experimental Institute for Citrus, then in } 1999 \text { into the Agricultural } \\
\text { Research Council and in 2007, finally, it became the Research Centre for } \\
\text { Citrus and Mediterranean Crops. }\end{array}$ & [16] \\
\hline
\end{tabular}

2014/2020 Sicilian Rural

Development Programme

ALLEGATO 14 PSR SICILIA (Piano

AO di sviluppo Rurale) 2014/2020

"I paesaggi a terrazze in Sicilia.

Metodologie per l'analisi, la tutela e

la valorizzazione"

The programme aims at implementing ecological-environmental and historical-cultural landscapes, so numerous in Sicily, for a collective project that measures the need to produce with the available native resources and with the environment features, specially oriented to

"Le Terre di Aci" Local Development

\section{$\mathrm{TO}$}

Participation Strategy

2014/2020 Rural Development Programme

"Tourism Economies"

Urban Redevelopment and

Sustainable Land Programme

TO Programma di Riqualificazione

Urbana e Sviluppo Sostenibile del Territorio,

Territorial Tourist District of the

Sicilian Region "Il Mare dell'Etna"

ERDF (European Regional

Development Fund) OP (Operative

Programme)

\section{ACIGREENWAY}

Cycle-pedestrian path on the old

route of the disused railway in the

Acireale Municipality within the

Greenways Project (taken from the

plan for non-motorized mobility in Sicily)

\begin{tabular}{llll}
\hline TO & $\begin{array}{l}\text { Heaven and Earth Ecomuseum } \\
\text { initiative of the Acireale Diocese }\end{array}$ & 2017 & $\begin{array}{l}\text { The open-air ecomuseum aims at promoting the huge artistic heritage, } \\
\text { as well as the tourism economy. }\end{array}$ \\
\hline TO & $\begin{array}{l}\text { Archaeological and landscape Park } \\
\text { of Catania and the "Valle dell'Aci" }\end{array}$ & 2019 & $\begin{array}{l}\text { The system of archaeological parks in Sicily was provided by regional } \\
\text { law No. 20/2000. The Archaeological and Landscape Park is a new } \\
\text { institution that only dates back to 2019. }\end{array}$ \\
\hline
\end{tabular}

The human activity of the past has produced a terraced landscape, with stairs, walls and small stone buildings, which has evolved over time, passing from the nineteenth-century vine plant to the subsequent citrus plant, especially in lemons.

It seems to disregard principles indicated in the Catania municipality programme: the traditional view of bringing the tourist incentive back to the receptive structures construction prevails, often in conflict with environmental sustainability criteria.

The district highlights the presence of two important attractors: the sea and Mount Etna, as recently declared Heritage of Humanity by UNESCO.

The main aim is the recovery of the old railway line dating back to the end of the 19th century. It was in 1864 when the council of the municipality of Acireale was gathered in several sessions to deliberate the construction of the railway station. In 1866, the first train arrived.

(1)

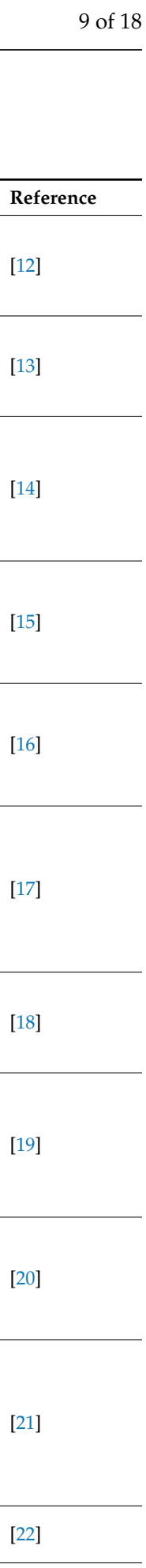

Regional Tourist Propaganda Plan 2016, 2018

TO
DRDF (European Regional
Development Fund) OP (Operative Development
Programme)

$2014-2020$

The plan describes the strategic and political guidelines for the development of Sicily, and aims at implementing a strategy for promoting the Sicily brand.

\section{\#Turismosicilia2020}

TO Three-year Tourism Development

Programme 2015-2017 of the Sicilian

2014-2020

The procedures for the concession for tourism activities involve 5 different figures (Port Authorities, Cultural Heritage Ministry,

Municipality, Regional Department, Civil Engineering Department). It Region Strategic Plan is necessary to simplify the authorization regimes.

FOCUS Tourism

Productive District “Agrumi di Sicilia-Le Vie della Zagara" 
Table 5. Cont.

\begin{tabular}{llll}
\hline Category & Plan & Year & Main Aim \\
\hline TO & $\begin{array}{l}\text { Catania Province Territorial Plan } \\
\text { Province Territorial Plan. Cognitive } \\
\text { Structural Asset, 2010 } \\
\text { Province Territorial Plan. Strategic } \\
\text { Asset Proposal, 2010 }\end{array}$ & 2010 & It underlines environmental, cultural and historical values. \\
\hline & $\begin{array}{l}\text { UNESCO Sites } \\
\text { Mount Etna (Italy) } \\
\text { Art of dry-stone walls } \\
\text { Submitted Application for the } \\
\text { historical centre of Acireale }\end{array}$ & $\begin{array}{l}\text { 2013 } \\
\text { in fieri }\end{array}$ & $\begin{array}{l}\text { Mount Etna was recognized as a World Heritage Site for its fundamental } \\
\text { role within the Mediterranean. Moreover, drywall structures are used as } \\
\text { shelters, for agriculture or cattle breeding, and testify to the methods } \\
\text { used, from prehistory to the present day, to organize life and } \\
\text { workspaces by optimizing local human and natural resources. }\end{array}$ \\
\hline
\end{tabular}

Subsequently, Tables 6 and 7, as defined in the "methods" section, summarizes the procedure followed for the evaluation of landscape performances in two sub-areas of the Timpa area. As regards the physical-environmental system, conditions of the two cases under study present comparable situations; similarly, for the historical-cultural system (albeit with small differences).

Table 6. Preserved landscape schedule 3/15.

\begin{tabular}{|c|c|c|c|}
\hline RS & ELEMENTS & RATE & DESCRIPTION \\
\hline \multirow{15}{*}{$\begin{array}{l}\text { PHYSICAL- } \\
\text { ENVIRONMENTAL } \\
\text { SYSTEM }\end{array}$} & \multicolumn{3}{|l|}{ VALUES } \\
\hline & SCI/SPAs & 2 & \multirow{4}{*}{$\begin{array}{l}\text { The value of each protected area was calculated according to the } \\
\text { protection level-that is, from } 0=\text { none; } 1=\text { local } 1 . ; 2=\text { natura2000 } \\
\text { network } 1 . ; 3=\text { regional } 1 . ; 4=\text { national } 1 .- \text { and to the percentage of the } \\
\text { protected area in relation to the whole area. The added value in this case } \\
\text { is related to the proximity to the S. Maria La Scala, Don Masi Timpa and } \\
\text { Gazzena geosites. }\end{array}$} \\
\hline & Nature Reserve & 3 & \\
\hline & Park & 0 & \\
\hline & Additional Interest & 2 & \\
\hline & \multicolumn{3}{|l|}{ DETRACTORS } \\
\hline & Seismic Restriction & 4 & \multirow{4}{*}{$\begin{array}{l}\text { Detractors in this system are related to problems expressed by constraints } \\
\text { linked to the soil features. Their evaluation was made according to the } \\
\text { percentage of surface in relation to the whole area-that is, from } 0=\text { none; } \\
1=0-25 ; 2=25-50 ; 3=50-75 ; 4=75-100 \% \text {. A further problem is given by } \\
\text { the data of the R4 and P4 surfaces, as mentioned in the recent updated } \\
\text { hydrogeological plans. }\end{array}$} \\
\hline & Hydro-Geological Restriction & 4 & \\
\hline & L. 445/1908 Restriction & 1 & \\
\hline & Additional Trouble & 3 & \\
\hline & \multicolumn{3}{|l|}{ UPCOMING PROJECTS } \\
\hline & Consolidation & 2 & \multirow{4}{*}{$\begin{array}{l}\text { The value of each element was calculated according to the } \\
\text { implementation level of the projects, as deduced from the urban planning } \\
\text { and planning tools of Table } 5 \text {-that is, from } 0=\text { none; } 1=0-25 ; 2=25-50 \text {; } \\
3=50-75 ; 4=75-100 \% \text { than expected. The additional value in this case } \\
\text { relates to any operations to combat run-off waters due to meteoric events. }\end{array}$} \\
\hline & Solution to prevent fire & 1 & \\
\hline & Solution to prevent people's danger & 1 & \\
\hline & Additional Intervention & 0 & \\
\hline \multirow{15}{*}{$\begin{array}{l}\text { LANDSCAPE-VISUAL } \\
\text { SYSTEM }\end{array}$} & VALUES & & \\
\hline & Landscape Restriction & 4 & \multirow{4}{*}{$\begin{array}{l}\text { The value of each element was calculated according to the constrained } \\
\text { surface as a percentage of the whole area-that is, from } 0=\text { none; } 1=0-25 \\
2=25-50 ; 3=50-75 ; 4=75-100 \% \text {. The added value in this case is related } \\
\text { to the panoramic view of historical paths. }\end{array}$} \\
\hline & Residuals (rasule, saje) & 3 & \\
\hline & Forests & 3 & \\
\hline & Additional Interest & 4 & \\
\hline & \multicolumn{3}{|l|}{ DETRACTORS } \\
\hline & $\begin{array}{l}\text { Wind-Power and Ground-Mounted } \\
\text { Photovoltaic Plants }\end{array}$ & 0 & \multirow{4}{*}{$\begin{array}{l}\text { Detractors in this system are referred to the impediments to the landscape } \\
\text { perception. Their evaluation was made as a function related to the } \\
\text { percentage of surface compared to the whole area-that is, from } 0=\text { none; } \\
1=0-25 ; 2=25-50 ; 3=50-75 ; 4=75-100 \% \text {. A further problem is given by } \\
\text { the interventions carried out along the coast with widespread } \\
\text { overbuilding. }\end{array}$} \\
\hline & Quarries & 0 & \\
\hline & Suburban sprawl & 2 & \\
\hline & Additional Trouble & 4 & \\
\hline & \multicolumn{3}{|l|}{ UPCOMING PROJECTS } \\
\hline & Dry-stone walls restoration & 1 & \multirow{4}{*}{$\begin{array}{l}\text { The value of each element was calculated according to the } \\
\text { implementation level of the projects, as deduced from the urban planning } \\
\text { and planning tools of Table } 5 \text {-that is, from } 0=\text { none; } 1=0-25 ; 2=25-50 \text {; } \\
3=50-75 ; 4=75-100 \% \text { than expected. The additional value in this case } \\
\text { relates to territorial services of peri-urban green spaces. }\end{array}$} \\
\hline & $\begin{array}{l}\text { Solution to prevent settlement } \\
\text { expansion }\end{array}$ & 4 & \\
\hline & Solution for people fruition & 3 & \\
\hline & Additional Intervention & 1 & \\
\hline
\end{tabular}


Table 6. Cont

\begin{tabular}{|c|c|c|c|}
\hline RS & ELEMENTS & RATE & DESCRIPTION \\
\hline \multirow{15}{*}{$\begin{array}{l}\text { HISTORICAL- } \\
\text { CULTURAL } \\
\text { SYSTEM }\end{array}$} & VALUES & & \\
\hline & Archaeological Restriction & 2 & \multirow{4}{*}{$\begin{array}{l}\text { The value of each element was calculated based on the number of the } \\
\text { restricted "common goods"-that is, from } 0=\text { none; } 1=0-5 ; 2=5-10 ; 3= \\
10-20 ; 4 \geq 20 \text {. The UNESCO proposal for the historic centre is relevant. } \\
\text { The added value in this case is related to the enhancement of the Testa } \\
\text { dell'Acqua watermill and the Miuccio spring complex. }\end{array}$} \\
\hline & Architectural Restriction & 4 & \\
\hline & Urban Planning Intervention & 1 & \\
\hline & Additional Interest & 4 & \\
\hline & \multicolumn{2}{|l|}{ DETRACTORS } & \\
\hline & Preservation Condition & 4 & \multirow{4}{*}{$\begin{array}{l}\text { Detractors of this system are related to the impediments to the use of } \\
\text { cultural heritage. A quantitative assessment of the conditions detected in } \\
\text { situ was carried out- that is, from } 0=\text { none; } 1=0-25 ; 2=25-50 ; 3=50-75 \text {; } \\
4=75-100 \% \text { of the whole area. A further problem is the possible lack of } \\
\text { knowledge even by local citizens. }\end{array}$} \\
\hline & Private Property & 3 & \\
\hline & Access Condition & 0 & \\
\hline & Additional Trouble & 0 & \\
\hline & \multicolumn{2}{|l|}{ UPCOMING PROJECTS } & \\
\hline & Historical Heritage Restoration & 4 & \multirow{4}{*}{$\begin{array}{l}\text { The value of each element was calculated according to the } \\
\text { implementation level of the projects, as deduced from the urban planning } \\
\text { and planning tools of Table 5-that is, from } 0=\text { none; } 1=0-25 ; 2=25-50 ; \\
3=50-75 ; 4=75-100 \% \text { than expected. The additional value is related to } \\
\text { the creation of the "Catania Archaeological and Landscape" and the } \\
\text { "Valle delle Aci" Parks. }\end{array}$} \\
\hline & $\begin{array}{l}\text { Solution to prevent settlement } \\
\text { abandonment }\end{array}$ & 0 & \\
\hline & Solution for public fruition & 4 & \\
\hline & Additional Intervention & 3 & \\
\hline \multirow{15}{*}{$\begin{array}{l}\text { AGRICULTURE- } \\
\text { PRODUCTIVE } \\
\text { SYSTEM }\end{array}$} & VALUES & & \\
\hline & Land Use for Agricultural Activities & 4 & \multirow{4}{*}{$\begin{array}{l}\text { The value of each of the elements was calculated based on the percentage } \\
\text { of land use surfaces related to the whole area-that is, from } 0=\text { none; } 1= \\
0-25 ; 2=25-50 ; 3=50-75 ; 4=75-100 \% \text {. The added value in this case is } \\
\text { related to the presence of the Mediterranean maquis. }\end{array}$} \\
\hline & Land Use for Agricultural Agri-food & 1 & \\
\hline & Land Use for Organic activities & 0 & \\
\hline & Additional Interest & 1 & \\
\hline & \multicolumn{2}{|l|}{ DETRACTORS } & \\
\hline & Industrial Sites & 0 & \multirow{4}{*}{$\begin{array}{l}\text { Detractors of this system are related to the impediments to the carrying } \\
\text { out of agricultural activities. A quantitative assessment of the conditions } \\
\text { detected in situ was carried out- that is, from } 0=\text { none; } 1=0-25 ; 2= \\
25-50 ; 3=50-75 ; 4=75-100 \text { of the whole area. A further problem is given } \\
\text { by the observation of the partial abandonment of cultivated terraces. }\end{array}$} \\
\hline & Special Districts & 2 & \\
\hline & Other & 2 & \\
\hline & Additional Trouble & 2 & \\
\hline & \multicolumn{2}{|l|}{ UPCOMING PROJECTS } & \\
\hline & Terraces Restoration & 0 & \multirow{4}{*}{$\begin{array}{l}\text { The value of each element was calculated according to the } \\
\text { implementation level of the projects, as deduced from the urban planning } \\
\text { and planning tools of Table } 5 \text {-that is, from } 0=\text { none; } 1=0-25 ; 2=25-50 \text {; } \\
3=50-75 ; 4=75-100 \% \text { than expected. The additional value in this case } \\
\text { relates to the study for the further agricultural park in the Timpa area. }\end{array}$} \\
\hline & $\begin{array}{l}\text { Solution to prevent agriculture } \\
\text { abandonment }\end{array}$ & 2 & \\
\hline & Solution for public fruition & 0 & \\
\hline & Additional Intervention & 2 & \\
\hline
\end{tabular}

Table 7. Endangered landscape schedule 8/30.

\begin{tabular}{|c|c|c|c|}
\hline RS & ELEMENTS & RATE & DESCRIPTION \\
\hline \multirow{15}{*}{$\begin{array}{l}\text { PHYSICAL- } \\
\text { ENVIRONMENTAL } \\
\text { SYSTEM }\end{array}$} & VALUES & & \\
\hline & SCI/SPAs & 2 & \multirow{4}{*}{$\begin{array}{l}\text { The value of each protected area was calculated according to the } \\
\text { protection level-that is, from } 0=\text { none; } 1=\text { local } 1 . ; 2=\text { natura } 2000 \\
\text { network } 1 . ; 3=\text { regional } 1 . ; 4=\text { national } 1 .- \text { and to the percentage of the } \\
\text { protected area in relation to the whole area. The added value in this case } \\
\text { is related to the proximity to the geosite in S. Maria La Scala. }\end{array}$} \\
\hline & Nature Reserve & 3 & \\
\hline & Park & 0 & \\
\hline & Additional Interest & 1 & \\
\hline & DETRACTORS & & \\
\hline & Seismic Restriction & 4 & \multirow{4}{*}{$\begin{array}{l}\text { Detractors in this system are related to problems expressed by constraints } \\
\text { linked to the soil features. Their evaluation was made according to the } \\
\text { percentage of surface in relation to the whole area-that is, from } 0=\text { none } \\
1=0-25 ; 2=25-50 ; 3=50-75 ; 4=75-100 \% \text {. A further problem is given by } \\
\text { the data of the R } 4 \text { and P4 surfaces, as mentioned in the recent updated } \\
\text { hydrogeological plans. }\end{array}$} \\
\hline & Hydro-Geological Restriction & 3 & \\
\hline & L. 445/1908 Restriction & 1 & \\
\hline & Additional Trouble & 1 & \\
\hline & \multicolumn{3}{|l|}{ UPCOMING PROJECTS } \\
\hline & Consolidation & 3 & \multirow{4}{*}{$\begin{array}{l}\text { The value of each element was calculated according to the } \\
\text { implementation level of the projects, as deduced from the urban planning } \\
\text { and planning tools of Table } 5 \text {-that is, from } 0=\text { none; } 1=0-25 ; 2=25-50 ; \\
3=50-75 ; 4=75-100 \% \text { than expected. The additional value in this case } \\
\text { relates to any operations to combat run-off waters due to meteoric events. }\end{array}$} \\
\hline & Solution to prevent fire & 1 & \\
\hline & Solution to prevent people's danger & 2 & \\
\hline & Additional Intervention & 0 & \\
\hline
\end{tabular}


Table 7. Cont

\begin{tabular}{|c|c|c|c|}
\hline RS & ELEMENTS & RATE & DESCRIPTION \\
\hline \multirow{15}{*}{$\begin{array}{l}\text { LANDSCAPE-VISUAL } \\
\text { SYSTEM }\end{array}$} & VALUES & & \\
\hline & Landscape Restriction & 4 & \multirow{4}{*}{$\begin{array}{l}\text { The value of each element was calculated according to the constrained } \\
\text { surface as a percentage of the whole area-that is, from } 0=\text { none; } 1=0-25 \text {; } \\
2=25-50 ; 3=50-75 ; 4=75-100 \% \text {. The added value in this case is related } \\
\text { to the widespread presence of terracing systems. }\end{array}$} \\
\hline & Residuals (rasule, saje) & 2 & \\
\hline & Forests & 2 & \\
\hline & Additional Interest & 4 & \\
\hline & \multicolumn{2}{|l|}{ DETRACTORS } & \\
\hline & $\begin{array}{l}\text { Wind-Power and Ground-Mounted } \\
\text { Photovoltaic Plants }\end{array}$ & 0 & \multirow{4}{*}{$\begin{array}{l}\text { Detractors in this system are referred to the impediments to the landscape } \\
\text { perception. Their evaluation was made as a function related to the } \\
\text { percentage of surface compared to the whole area-that is, from } 0=\text { none; } \\
1=0-25 ; 2=25-50 ; 3=50-75 ; 4=75-100 \% \text {. A further problem is given by } \\
\text { the untapped scenic routes. }\end{array}$} \\
\hline & Quarries & 0 & \\
\hline & Suburban sprawl & 3 & \\
\hline & Additional Trouble & 4 & \\
\hline & \multicolumn{2}{|l|}{ UPCOMING PROJECTS } & \\
\hline & Dry-stone walls restoration & 1 & \multirow{4}{*}{$\begin{array}{l}\text { The value of each element was calculated according to the } \\
\text { implementation level of the projects, as deduced from the urban planning } \\
\text { and planning tools of Table } 5 \text {-that is, from } 0=\text { none; } 1=0-25 ; 2=25-50 \text {; } \\
3=50-75 ; 4=75-100 \% \text { than expected. The additional value in this case } \\
\text { relates to the recent census of local wells and springs. }\end{array}$} \\
\hline & $\begin{array}{l}\text { Solution to prevent settlement } \\
\text { expansion }\end{array}$ & 0 & \\
\hline & Solution for people fruition & 3 & \\
\hline & Additional Intervention & 1 & \\
\hline \multirow{15}{*}{$\begin{array}{l}\text { HISTORICAL- } \\
\text { CULTURAL } \\
\text { SYSTEM }\end{array}$} & \multicolumn{2}{|l|}{ VALUES } & \\
\hline & Archaeological Restriction & 0 & \multirow{4}{*}{$\begin{array}{l}\text { The value of each element was calculated based on the number of the } \\
\text { restricted "common goods" - that is, from } 0=\text { none; } 1=0-5 ; 2=5-10 ; 3= \\
10-20 ; 4 \geq 20 \text {. The UNESCO proposal for the historic centre is relevant. } \\
\text { The added value in this case relates to the disused railway. }\end{array}$} \\
\hline & Architectural Restriction & 1 & \\
\hline & Urban Planning Intervention & 1 & \\
\hline & Additional Interest & 1 & \\
\hline & DETRACTORS & & \\
\hline & Preservation Condition & 1 & \multirow{4}{*}{$\begin{array}{l}\text { Detractors of this system are related to the impediments to the use of } \\
\text { cultural heritage. A quantitative assessment of the conditions detected in } \\
\text { situ was carried out- that is, from } 0=\text { none; } 1=0-25 ; 2=25-50 ; 3=50-75 \text {; } \\
4=75-100 \% \text { of the whole area. A further problem is related to the lack of } \\
\text { knowledge of local cultural goods by inhabitants. }\end{array}$} \\
\hline & Private Property & 4 & \\
\hline & Access Condition & 3 & \\
\hline & Additional Trouble & 1 & \\
\hline & \multicolumn{2}{|l|}{ UPCOMING PROJECTS } & \\
\hline & Historical Heritage Restoration & 4 & \multirow{4}{*}{$\begin{array}{l}\text { The value of each element was calculated according to the } \\
\text { implementation level of the projects, as deduced from the urban planning } \\
\text { and planning tools of Table } 5 \text {-that is, from } 0=\text { none; } 1=0-25 ; 2=25-50 ; \\
3=50-75 ; 4=75-100 \% \text { than expected. The additional value in this case } \\
\text { relates to the restoring of small seaports. }\end{array}$} \\
\hline & $\begin{array}{l}\text { Solution to prevent settlement } \\
\text { abandonment }\end{array}$ & 0 & \\
\hline & Solution for public fruition & 3 & \\
\hline & Additional Intervention & 1 & \\
\hline \multirow{15}{*}{$\begin{array}{l}\text { AGRICULTURE- } \\
\text { PRODUCTIVE } \\
\text { SYSTEM }\end{array}$} & VALUES & & \\
\hline & Land Use for Agricultural Activities & 4 & \multirow{4}{*}{$\begin{array}{l}\text { The value of each of the elements was calculated based on the percentage } \\
\text { of land use surfaces related to the whole area-that is, from } 0=\text { none; } 1= \\
0-25 ; 2=25-50 ; 3=50-75 ; 4=75-100 \% \text {. The added value in this case is } \\
\text { related to the presence of the Mediterranean maquis. }\end{array}$} \\
\hline & Land Use for Agricultural Agri-food & 0 & \\
\hline & Land Use for Organic activities & 0 & \\
\hline & Additional Interest & 1 & \\
\hline & DETRACTORS & & \\
\hline & Industrial Sites & 1 & Detractors of this system are related to the impediments to the carrying \\
\hline & Special Districts & 2 & out of agricultural activities. A quantitative assessment of the conditions \\
\hline & Other & 4 & $25-50 ; 3=50-75 ; 4=75-100$ of the whole area. A further problem \\
\hline & Additional Trouble & 4 & ids on the widespread abandonment of cultivated terraces. \\
\hline & UPCOMING PROJECTS & & \\
\hline & Terraces Restoration & 0 & The value of each element was calculated according to the \\
\hline & $\begin{array}{l}\text { Solution to prevent agriculture } \\
\text { abandonment }\end{array}$ & 2 & $\begin{array}{l}\text { implementation level of the projects, as deduced from the urban planning } \\
\text { and planning tools of Table } 5 \text {-that is, from } 0=\text { none; } 1=0-25 ; 2=25-50 \text {; }\end{array}$ \\
\hline & Solution for public fruition & 0 & relates to the possible dissemination of knowledge of the \\
\hline & Additional Intervention & 0 & agro-food heritage. \\
\hline
\end{tabular}

The greatest differences are recorded for the perceptive landscape system, where it is evident that in the case of the Pietramonaca district, the high values are accompanied by 
strong detractors, but above all, the upcoming projects are insufficient. A tricky situation occurs for the agricultural-productive system where the value of detractors is very strong and above all increased by the abandonment factor; moreover, there are almost no upcoming projects at all. The set of these considerations leads to including this area in the category of endangered landscapes (following Tables 6 and 7). As far as the Chiazzette landscape is concerned, strongly positive elements emerge, especially with respect to upcoming projects, in all systems and in particular on perception (abandonment of panoramic points, made more usable even with numerous interventions aimed at safety and park proposals). The set of these considerations leads to inclusion of this area in the category of preserved landscapes (following Tables 6 and 7).

To sum up, in the first instance analyses were carried out; subsequently, scores to values, detractors and UP were assigned; finally, the formula was used (in order to classify areas in the different typologies of landscape conservation).

The catalogued landscapes are: endangered: 30; residual: 12; disappeared: 10 and preserved: 15 .

In this paper, by way of example, two cases are reported, relating to the conditions of preserved and endangered landscapes in the Timpa sample area, as shown in Figure 2.

As can be deduced from it, many of the landscapes in danger derive from physical conditions, which also in the form of the methodology used weigh heavily, while in the case of preserved landscapes, the weight of upcoming projects is relevant, even if not always in the proportion that was expected.

The work, however, also concerned the other two types of landscape, namely the residuals and the disappeared. As for the former, it is mostly woods, peri-urban vegetable gardens of ancient plants, and ancient paths such as the 'trazzere' for livestock movement. As for the latter, the cases are very different from each other: for example, there is the Grotta delle Colombe which has now completely disappeared, the loss of coastline continuity due to aggressive building interventions, and the areas in which collapsed historic buildings fall into neglect.

Only one example for each typology is illustrated in Figure 3. 


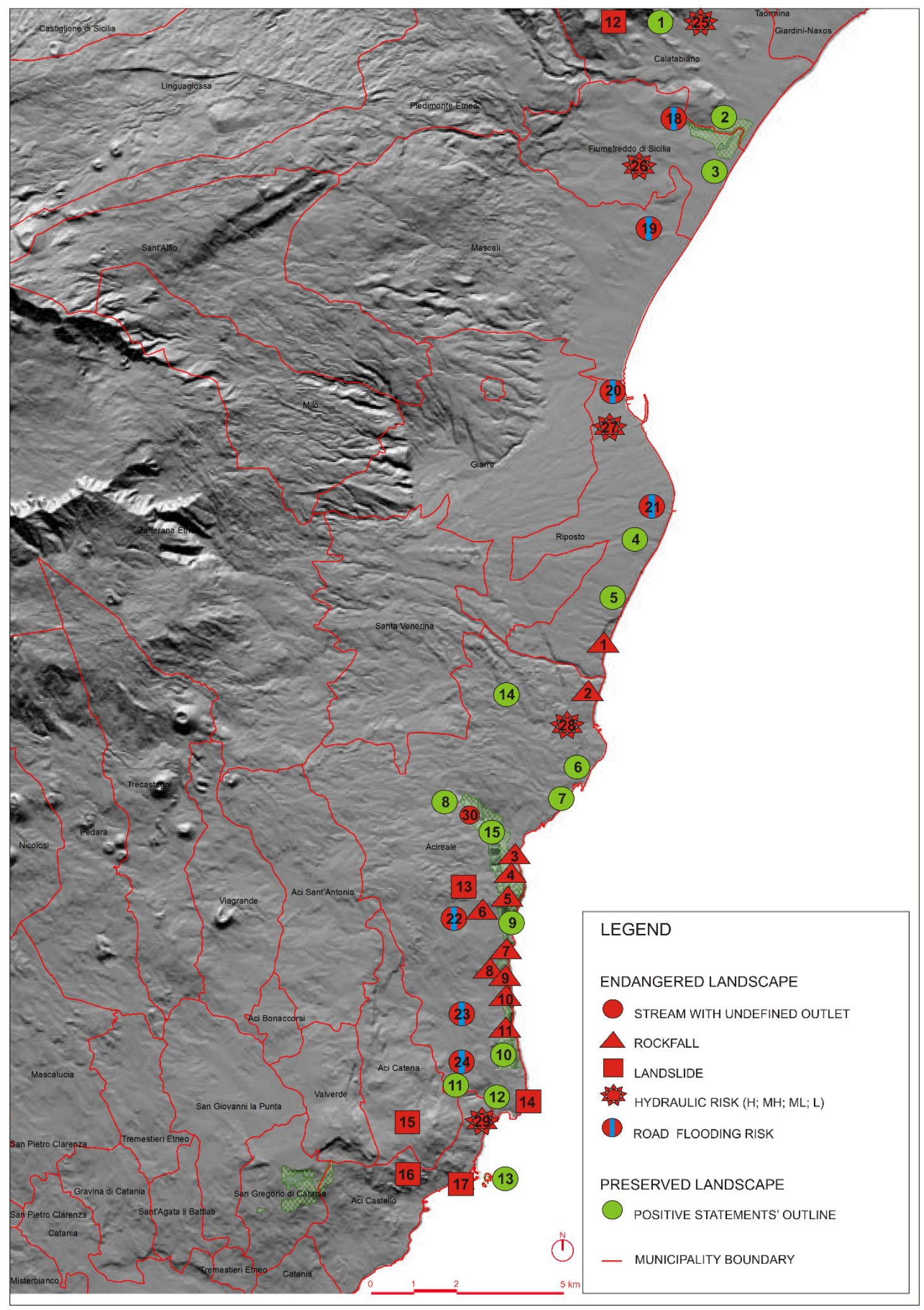

Figure 2. Sample area analysis. (Source: processing in ArcGis by l.a.co.s.t.a. Laboratory, Cialdea 2020). 


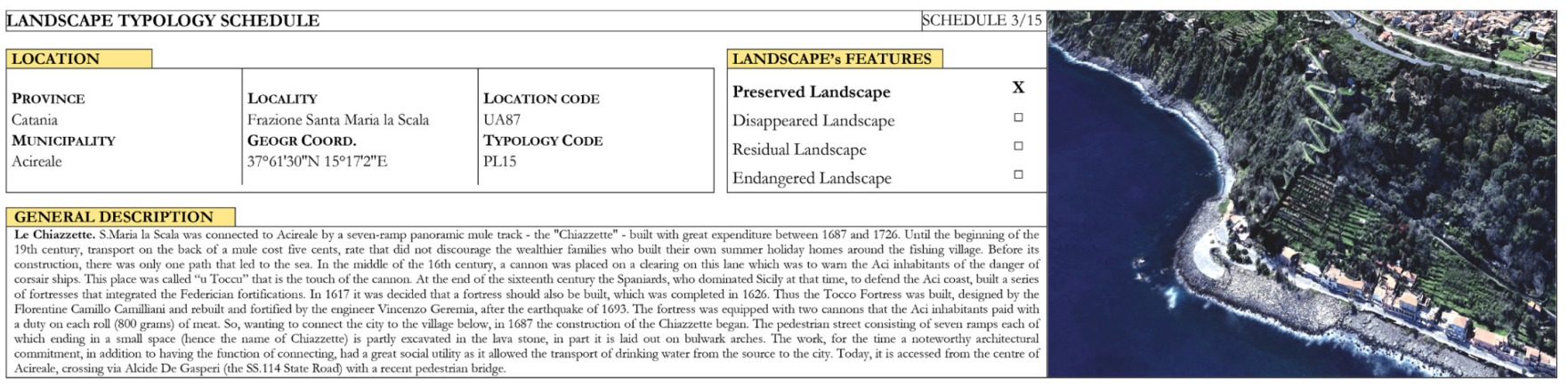

\begin{tabular}{|c|c|c|c|c|c|}
\hline \multicolumn{3}{|c|}{ LANDSCAPE TYPOLOGY S } & & E 4/10 & \multirow{3}{*}{ 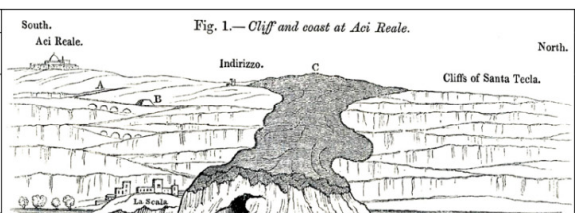 } \\
\hline \multicolumn{3}{|l|}{ LOCATION } & LANDSCAPE'S FEATURE & & \\
\hline $\begin{array}{l}\text { Province } \\
\text { Catania } \\
\text { MUNICIPALITY } \\
\text { Acireale }\end{array}$ & $\begin{array}{l}\text { LOCALITY } \\
\text { Santa Maria la Scala } \\
\text { GEOGR COORD. } \\
37^{\circ} 62^{2} 07^{\prime \prime N} 15^{\circ} 17^{\prime} 49^{\prime \prime} \mathrm{E}\end{array}$ & $\begin{array}{l}\text { LOCATION CODE } \\
\text { UA87 } \\
\text { TYPOLOGY CODE } \\
\text { DL10 }\end{array}$ & $\begin{array}{l}\text { Preserved Landscape } \\
\text { Disappeared Landscape } \\
\text { Residual Landscape } \\
\text { Endangered Landscape }\end{array}$ & $\begin{array}{l}\mathrm{x} \\
\square \\
\square\end{array}$ & \\
\hline & $=$ \\
\hline \multicolumn{5}{|c|}{ 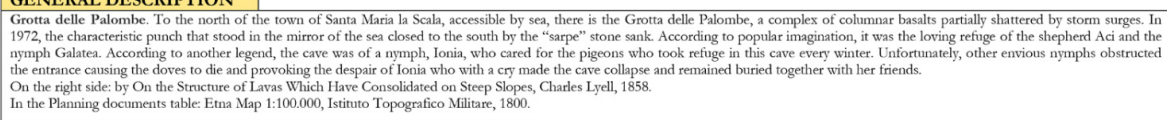 } & $\begin{array}{l}\text { A. Upper part of the road called the Sealazza. } \\
\text { B. Bastione del Toceco. } \\
\text { c. I. Lara-current which descends the clifif to the Grotto delle Palombe. } \\
\text { D. Grotto delle Palombe. }\end{array}$ \\
\hline
\end{tabular}

(a)
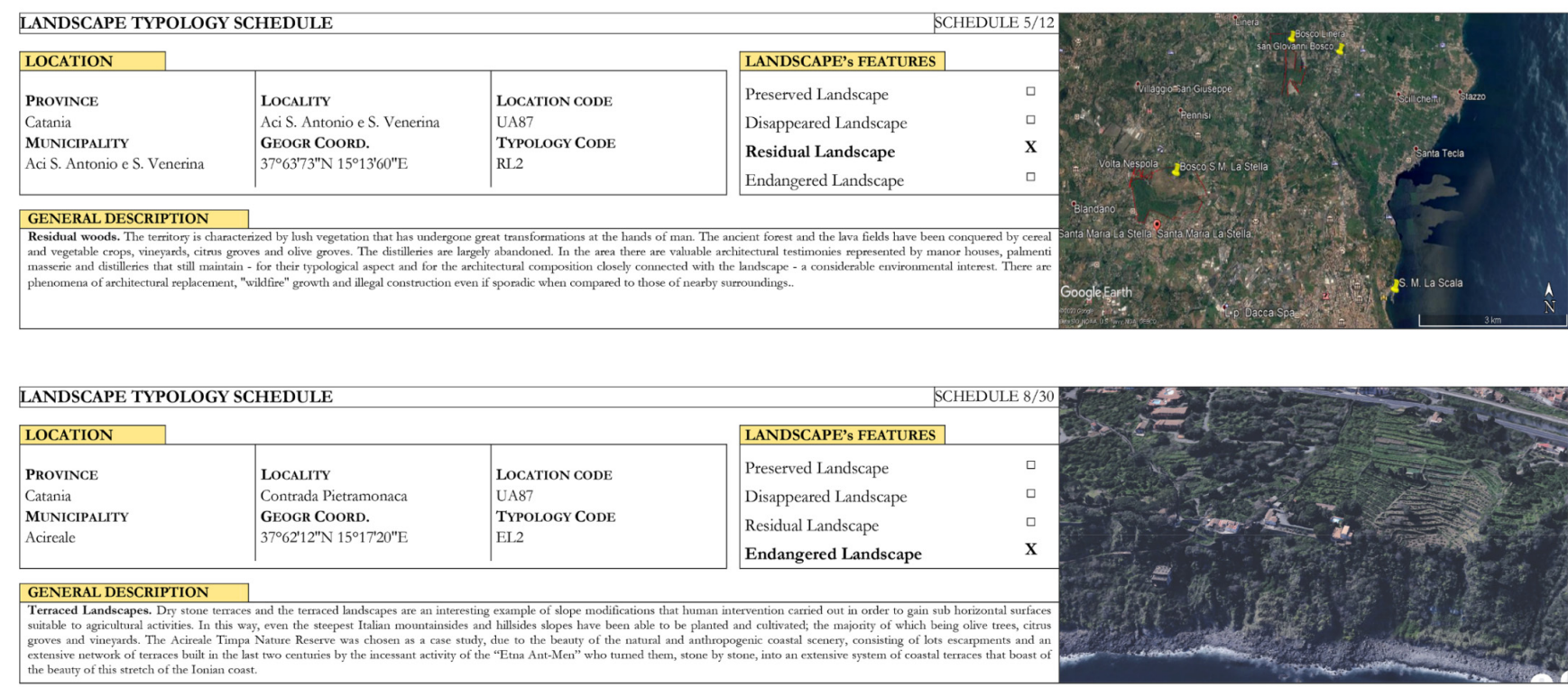

(b)

Figure 3. Part 1 (a): Landscape performances: preserved and disappeared (author's own elaboration, 2020). Part 2 (b): landscape performances: residual and endangered (author's own elaboration, 2020).

\section{Conclusions}

The relationship between the needs of economic development and protected areas is a topic that mainly involves coastal areas. This is a highly conflicting issue, especially in the countries of the Mediterranean Basin and particularly in Italy. The case study examined the largest island in the basin, Sicily, which displays valuable landscapes simultaneously with remarkable transformation, mostly due to residential settlements for tourism purposes and second homes.

The results gained should have a wide potential, expressly open to integrations with the various scientific disciplines dealing with landscape. During the work, one of the 
situations that deserves more attention was found to be the condition of many terraced landscapes. The most interesting cases were found on the coast where the mountain falls steeply into the sea. These areas were traditionally dedicated to agriculture, but, especially in the more industrialized countries, the phenomenon of abandoning agricultural activities occurred in the middle of the last century and still occurs nowadays.

In Italy, as in every Mediterranean Basin European country, the fundamental problem, therefore, is abandonment with the consequent landscape degradation. While needs for the agriculture maintenance highlight the shortcomings above all of a typicality of its products, urban planning tools often favour residential destinations, especially related to tourism purposes. This, in fact, appears to be the emerging problem, especially because of the neighbouring nature reserves.

This work aimed to provide a methodology for verifying these contrasting needs, and therefore, a system and a database have been created and implemented within the geographic information system, elaborating a comparison between environmental requirements and development strategies. Great attention has been paid to the in-depth examination of the wishes expressed in the numerous planning and economic programming tools, which have been issued in recent years, in order to point out the inconsistencies that they very often bring.

To expand this research, the quality of the GIS can undoubtedly be improved. As a matter of fact, it was necessary to digitize many of the urban planning tools or to make digital - with territorial reference-some information deriving from the written documents, and certainly this phase of work would require a general data validation. However, the main issue is related to the land use changes, and in particular to the maintenance of the peri-urban agriculture $[6,12-14,30,33,58-60]$.

Therefore, terraced landscapes are interesting from multiple points of view. What is less addressed by the literature is precisely the main interest of this research: the discrepancy between the will of the planning tools and the real situation, which often changes the aspect of the landscape in a sudden way and, more often than not, as a result of calamitous events. The planning and management tools (which do not always have the same aim) therefore clash with the rapid evolution of the landscape.

The effort was to compare two different worlds, that of researchers who mainly address the needs of landscape conservation, with those who deal with the future development tools of those territories. The detected inconsistencies between development needs and conservation needs always have consequences on the territory. The main product of this research phase is the introduction of the landscape conservation typologies; they can be an innovative contribution to investigations. The extension of this classification to the entire regional coastal area will constitute a benchmark for local authorities, who have a duty to safeguard the landscape and at the same time to provide for local economic development.

Supplementary Materials: The following are available online at https:/ / www.mdpi.com/article/10 .3390/su13126621/s1.

Author Contributions: Conceptualization and supervision, D.C. and S.P.; investigation and writing, D.C. and S.P. Both authors have read and agreed to the published version of the manuscript.

Funding: This work was supported by the Regione Molise, under agreement with the l.a.co.s.t.a. Laboratory (Director D. Cialdea) of the University of Molise for the creation of the 'New Regional Landscape Plan of Molise', DEL. No. 406 (25-10-2019), published in BURM No. 47 (16 November 2019). Available online: http://cloud.urbi.it/urbi/progs/urp/ur2DE001.sto?StwEvent=101\&DB_ NAME=11200158\&IdDelibere=75417 (accessed on 10 April 2021).

Institutional Review Board Statement: Not applicable.

Informed Consent Statement: Not applicable.

Data Availability Statement: Not applicable.

Conflicts of Interest: The authors declare no conflict of interest. 


\section{References}

1. Council of Europe. European Landscape Convention, European Treaty Series-No. 176; Council of Europe Publishing: Strasbourg, France, 2000.

2. Council of Europe. Landscape in Planning Policies and Governance, No 89; Council of Europe Publishing: Strasbourg, France, 2009.

3. Council of Europe. Landscape Dimensions. Reflections and Proposals for the Implementation of the European Landscape Convention; Council of Europe Publishing: Strasbourg, France, 2017.

4. Antrop, A. Landscape change and the urbanization process in Europe. Landsc. Urban Plan. 2004, 67, 9-26. [CrossRef]

5. Antrop, A. Why landscapes of the past are important for the future. Landsc. Urban Plan. 2005, 70, 21-34. [CrossRef]

6. Mcdonald, R.; Forman, R.T.T.; Kareiva, P.; Neugartena, R.; Salzer, D.; Fisher, J. Urban effects, distance, and protected areas in an urbanizing world. Landsc. Urban Plan. 2009, 93, 63-75. [CrossRef]

7. Rodrigo de la O Cabrera, M.; Marine, N.; Escudero, D. Spatialities of cultural landscapes: Towards a unified vision of Spanish practices within the European Landscape Convention. Eur. Plan. Stud. 2020, 28, 1877-1898. [CrossRef]

8. Leone, A. Ambiente e Pianificazione. Uso del Suolo e Processi di Sostenibilità; Franco Angeli Editore: Milano, Italy, 2019. (In Italian)

9. Cialdea, D. The city and natural resources. Tema. J. Land Use Mobil. Environ. 2020, 14, 67-79. [CrossRef]

10. Cialdea, D.; Pompei, C. The territorial framework of the river courses: A new methodology in evolving perspectives. Eur. Plan. Stud. 2020, 29, 1-20. [CrossRef]

11. Dorning, M.A.; Koch, J.; Shoemaker, D.A.; Meentemeyer, R. Simulating urbanization scenarios reveals tradeoffs between conservation planning strategies. Landsc. Urban Plan. 2015, 136, 28-39. [CrossRef]

12. La Rosa, D.; Privitera, R. Characterization of non-urbanized areas for land-use planning of agricultural and green infrastructure in urban contexts. Landsc. Urban Plan. 2013, 109, 94-106. [CrossRef]

13. Arnold, J.; Kleemann, J.; Fürst, C.A. Differentiated Spatial Assessment of Urban Ecosystem Services Based on Land Use Data in Halle, Germany. Land 2018, 7, 101. [CrossRef]

14. Shaw, B.J.; van Vliet, J.; Verburg, P.H. The peri-urbanization of Europe: A systematic review of a multifaceted process. Landsc. Urban Plan. 2020, 196, 103733. [CrossRef]

15. Honeck, E.; Moilanen, A.; Guinaudeau, B.; Wyler, N.; Schlaepfer, M.A.; Martin, P.; Sanguet, A.; Urbina, L.; von Arx, B.; Massy, J.; et al. Implementing Green Infrastructure for the Spatial Planning of Peri-Urban Areas in Geneva, Switzerland. Sustainability 2020, 12, 1387. [CrossRef]

16. European Environmental Agency (EEA). Urban Sprawl in Europe. The Ignored Challenge, Report No 10/2006; European Environmental Agency (EEA): Copenhagen, Denmark, 2006.

17. European Environmental Agency (EEA). Urban Sprawl in Europe, Report No 11/2016; European Environmental Agency: Copenhagen, Denmark, 2016.

18. Nadin, V.; Stead, D. European spatial planning systems, social models and learning. Plan. Rev. 2008, 44, 35-47. [CrossRef]

19. Vizzari, M.; Sigura, M. Landscape sequences along the urban-rural-natural gradient. Landsc. Urban Plan. 2015, 140, 42-55. [CrossRef]

20. Zasada, I.; Häfner, K.; Schaller, L.; van Zanten, B.T.; Lefebvre, M.; Malak-Rawlikowska, A.; Nikolov, D.; Rodríguez-Entrena, M.; Manrique, R.; Ungaro, F.; et al. A conceptual model to integrate the regional context in landscape policy, management and contribution to rural development: Literature review and European case study evidence. Geoforum 2017, 82, 1-12. [CrossRef]

21. Cialdea, D. Landscape Features of Coastal Waterfronts: Historical Aspects and Planning Issues. Sustainability 2020, 12, 2378. [CrossRef]

22. UNESCO. Intangible Cultural Heritage List. 2020. Available online: https:/ /ich.unesco.org/en/lists (accessed on 9 October 2020).

23. UNESCO World Heritage Centre. World Heritage Agricultural Landscapes. World Heritage. 2013, p. 69. Available online: https: / /ich.unesco.org (accessed on 9 October 2020).

24. UNESCO World Heritage Centre. Cultural Landscapes. 2020. Available online: https://whc.unesco.org/ (accessed on 9 October 2020).

25. Dorren, L.; Rey, F. A Review of the Effect of Terracing on Erosion; Scape, Soil Conservation and Protection for Europe, 2004; pp. 97-108. Available online: http:/ / ecorisq.org/docs / (accessed on 3 March 2021).

26. Grove, A.T.; Rackham, O. The Nature of Mediterranean Europe, an Ecological History; Yale University Press: New Haven, CT, USA, 2003.

27. Arnàez, J.; Lana-Renault, N.; Lasanta, T.; Ruiz-Flano, P.; Castroviejo, J. Effects of farming terraces on hydrological and geomorphological processes. A review. Catena 2015, 128, 122-134. [CrossRef]

28. Tarolli, P.; Preti, F.; Romano, N. Terraced landscapes. Anthropocene 2014, 6, 10-25. [CrossRef]

29. Cammeraat, L.H. Scale dependent thresholds in hydrological and erosion response of a semi-arid catchment in southeast Spain. Agric. Ecosyst. Environ. 2004, 104, 317-332. [CrossRef]

30. Perlotto, C.; D'Agostino, V. Performance assessment of bench-terraces through 2-D modelling: Performance assessment of bench-terraces. Land Degrad. Dev. 2016, 29. [CrossRef]

31. Agnoletti, M.; Errico, A.; Santoro, A.; Dani, A.; Preti, F. Terraced landscapes and hydrogeological risk. effects of land abandonment in Cinque Terre (Italy) during Severe Rainfall Events. Sustainability 2019, 11, 235. [CrossRef]

32. Barbera, G.; Cullotta, S.; Rossi-Doria, I.; Rühl, J.; Rossi-Doria, B. I Paesaggi a Terrazze in Sicilia; ARPA: Palermo, Italy, 2010.

33. Barbera, G.; Biasi, R.; Marino, D. I Paesaggi Agrari Tradizionali; Palmieri, M., Ed.; FrancoAngeli: Milano, Italy, 2014.

34. Privitera, S. Geomorphological characters of the Etna coast (eastern Sicily): Examples of irreversible environmental degradation due to anthropic activities. Geologie 2010, 160, 173-177. 
35. Privitera, S. Il territorio del Monte Etna da Parco Regionale a Patrimonio Naturale Mondiale dell'UNESCO. Geotema 2018, 57, 143-148. (In Italian)

36. Regione Siciliana. Regional Decree 14 March 1984, no. 84 Costituzione della riserva naturale «La Timpa», ricadente nel comune di Acireale. Available online: http:/ / www.regione.sicilia.it/agricolturaeforeste/ (accessed on 9 October 2020).

37. Regione Siciliana. Regional Decree 23 Avril 1999 Istituzione della riserva naturale orientata La Timpa, ricadente nel territorio del comune di Acireale, 1999. Available online: http:/ / www.regione.sicilia.it/agricolturaeforeste/ (accessed on 9 October 2020).

38. Melzer, R.; Ezzy, L.; Hines, H.B. Health checks: A simple tool for assessing the condition of values and effectiveness of reserve management. Parks 2019. [CrossRef]

39. Dolomiti Unesco Rete delle Aree Protette. La Rete Delle Aree Protette Dolomiti Unesco, 2014. Available online: https://www. dolomitiunesco.info/ (accessed on 9 January 2020).

40. Cialdea, D. Planning activities in coastal areas italian and cross-border approaches along the adriatic sea. Int. J. Sustain. Dev. Plan. 2017, 12, 853-866. [CrossRef]

41. Cialdea, D. Smart land: Regeneration and sustainability in lost scenarios and new performances. In Smart Planning: Sustainability and Mobility in the Age of Change; Rocco, P., Fistola, R., Gargiulo, C., Eds.; Springer International: Cham, Switzerland, 2018; pp. 1-25. [CrossRef]

42. Cialdea, D. Spatial evolutions between identity values and settlements changes. Territorial analyses oriented to landscape regeneration. In Planning, Nature and Ecosystem Services; Gargiulo, C., Zoppi, C., Eds.; Fedoapress: Napoli, Italy, 2019; pp. 10-19. [CrossRef]

43. Peano, A.; Cassatella, C. (Eds.) Landscape Indicators. Assessing and Monitoring Landscape Quality; Springer: Dordrecht, NL, USA, 2011.

44. Cialdea, D. (Ed.) Environmental Assessment Interreg Report 3 GES.S.TER./Interreg IIIA; Arti Grafiche La Regione: Campobasso, Italy, 2007.

45. Regione Molise. Agreement with the University of Molise-l.a.co.s.t.a. Laboratory (Director Prof. D. Cialdea) for Preliminary Researches for the "New Regional Landscape Plan of Molise". Available online: http://www3.regione.molise.it/flex/cm/pages/ ServeBLOB.php/L/IT/IDPagina/1 (accessed on 11 February 2011).

46. Regione Molise. Agreement with the University of Molise-l.a.co.s.t.a. Laboratory BURM No. 47 (16.11.2019). Available online: http: / / cloud.urbi.it/urbi/progs/urp/ur2DE001.sto?StwEvent=101\&DB_NAME=11200158\&IdDelibere=75417 (accessed on 10 April 2021).

47. Privitera, D.; Privitera, S. Laboratory as experiment in field learning: An application in a touristic city. J. Res. Didact. Geogr. 2018, 1, 77-88. [CrossRef]

48. Simeonova, V.; van der Valk, A. Environmental policy integration. Land Use Policy 2016, 57, 80-93. [CrossRef]

49. Ledda, A.; Anna Di Cesare, E.; Satta, G.; Calia, G.; Arras, F.; Congiu, A.; Manca, E.; De Montis, A. Adaptation to Climate Change and Regional Planning: A Scrutiny of Sectoral Instruments. Sustainability 2020, 12, 3804. [CrossRef]

50. Tewdwr-Jones, M.; Bishop, K.; Wilkinson, D. Euroscepticism. Political Agendas and Spatial Planning: British National and Regional Planning Policy in Uncertain Times. Eur. Plan. Stud. 2000, 8, 651-668. [CrossRef]

51. Getimis, P. Comparing spatial planning systems and planning cultures in Europe. Plan. Pract. Res. 2012, 27, 25-40. [CrossRef]

52. Liberato, D.; Alén, E.; Liberato, P.; Domínguez, T. Governance and cooperation in Euroregions: Border tourism between Spain and Portugal. Eur. Plan. Stud. 2018. [CrossRef]

53. Amdam, J. Structure and strategy for regional learning and innovation. Eur. Plan. Stud. 2003, 11, 439-459. [CrossRef]

54. Rudolf, S.C.; Grădinaru, S.R.; Hersperger, A.M. Impact of planning mandates on local plans. Eur. Plan. Stud. 2017, 25, 2192-2211. [CrossRef]

55. Brunetta, G.; Voghera, A. Evaluating landscape for shared values: Tools, principles, and methods. Landsc. Res. 2008, 33, 71-87. [CrossRef]

56. De Montis, A. Impacts of the European landscape convention on national planning systems. Landsc. Urban Plan. 2014, 124, 53-65. [CrossRef]

57. De Montis, A. Measuring the performance of planning: The conformance of Italian landscape planning practices with the European Landscape Convention. Eur. Plan. Stud. 2016, 24, 1727-1745. [CrossRef]

58. Finn, D.; Hopkins, L.D.; Wempe, M. The information system of plans approach: Using and making plans for landscape protection. Landsc. Urban Plan. 2007, 81, 132-145. [CrossRef]

59. Gambino, R.; Peano, A. (Eds.) Nature Policies and Landscape Policies. Towards an Alliance; Springer: Cham, Switzerland, 2015. [CrossRef]

60. Wissen Hayek, U.; von Wirth, T.; Neuenschwander, N.; Grêt-Regamey, A. Organizing and facilitating Geodesign processes. Landsc. Urban Plan. 2016, 156, 59-70. [CrossRef] 